\title{
Strategi Operasi Berbasis Lean Six Sigma sebagai Usaha Peningkatan Service Level
}

\author{
Authors: \\ Rini Mulyani Sari ${ }^{1}$ \\ Evan Nugraha ${ }^{2}$ \\ Affiliations: \\ ${ }^{1}$ Teknik Industri, Fakultas \\ Teknik, Universitas Widyatama \\ ${ }^{2}$ Teknik Industri, Fakultas \\ Teknik, Universitas \\ Muhammadiyah Bandung \\ Corresponding Author: \\ Rini Mulyani Sari \\ Emails: \\ 1rini210283@gmail.com \\ ²noe.rievan@gmail.com \\ Article History: \\ Received: April11, 2019 \\ Revised : May 4, 2019 \\ Accepted: June 24, 2019 \\ How to cite this article: \\ Sari, R. M., \& Nugraha, E. \\ (2019). Strategi Operasi \\ Berbasis Lean Six Sigma \\ sebagai Usaha Peningkatan \\ Service Level. Organum: \\ Jurnal Saintifik Manajemen \\ dan Akuntansi, 2(1), 25-36. doi \\ https://doi.org/10.35138/organu \\ $\underline{\text { m.v2i1.59 }}$
}

Journal Homepage: ejournal.winayamukti.ac.id/ind ex.php/Organum

Copyright:

๑) 2019. Published by Organum: Jurnal Saintifik Manajemen dan Akuntansi. Faculty of Economics and Business. Winaya Mukti University.

\begin{abstract}
The development of the automotive industry in Indonesia made the level of competition even tighter, so Auto2000 Setiabudhi tried to provide periodic maintenance services, especially for the replacement of New Avanza Veloz disc brakes. The purpose of this study was to reduce the processing time of the New Avanza Veloz disc brake replacement to increase the Auto2000 Setiabudhi service level. However, the results of observations found that the time for disc brake replacement was exceeded the requirements set by the company. The observation was carried out for two years, from 2017 to 2018. Obtained also information from observations that there was an increase in the processing time gap of $0.84 \%$, an increase in service level gap of $5.17 \%$, while waste that occurred was waste waiting and motion. The method used in this study is based on Lean Six Sigma. The results obtained after improvements were made to a reduction in processing time by $50 \%$, reduction in waste waiting, and motion and the achievement of service levels by $100 \%$.
\end{abstract}

Keywords: Waste; disc brake; lean six sigma.

Abstrak. Perkembangan industri otomotif di Indonesia membuat tingkat persaingan semakin ketat, sehingga Auto2000 Setiabudhi berusaha memberikan jasa perawatan berkala khususnya untuk penggantian disc brake New Avanza Veloz. Tujuan penelitian ini adalah untuk mereduksi waktu proses penggantian disc brake New Avanza Veloz sehingga dapat meningkatkan service level Auto2000 Setiabudhi. Namun, dari hasil observasi yang dilakukan didapati bahwa waktu penggantian disc brake ternyata melampaui persyaratan yang telah ditetapkan perusahaan. Observasi dilakukan selama 2 tahun yaitu dari tahun 2017 hingga tahun 2018. Didapatkan juga informasi dari observasi bahwa terjadi peningkatan gap waktu proses sebesar $0,84 \%$, peningkatan gap service level sebesar $5,17 \%$, sedangkan waste yang terjadi adalah waste waiting dan motion. Metode yang digunakan dalam penelitian ini berbasis Lean Six Sigma. Hasil yang didapat setelah dilakukan perbaikan adalah terjadinya reduksi waktu proses sebesar $50 \%$, reduksi waste waiting, serta motion dan pencapaian service level sebesar $100 \%$.

Kata Kunci: Waste; disc brake; lean six sigma.

\section{Pendahuluan}

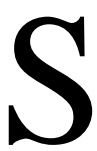
ecara keseluruhan industri otomotif saat ini sedang berkembang dengan pesat. Jika dilihat data statistik Gabungan Industri Kendaraan Bermotor Indonesia (GAIKINDO) saat ini, produksi otomotif di Indonesia sudah mencapai 597.522 unit, bahkan kapasitas produksi otomotif di Indonesia mencapai 2,2 juta unit secara konsisten dalam waktu 12 bulan. Industri otomotif juga diyakini berkem- 
bang di masa mendatang. Kondisi pasar yang luas dan perubahan kebijakan dapat memberikan stimulus yang luar biasa (Hartanto, 2017). Lokasi industri otomotif menjadi tulang punggung pihak berwenang dalam mengetahui target pertumbuhan industri sebesar $5,67 \%$ bersama dengan sektor industri elektronik, kimia farmasi, serta industri makanan dan minuman.

Tumbuhnya sektor industri otomotif dan sektor industri lainnya secara keseluruhan sangat penting karena industri memberikan kontribusi yang paling penting bagi Produk Domestik Bruto (PDB) nasional sebesar 20 persen. Ketika terjadi penggabungan dengan industri turunannya, kontribusinya dapat mencapai lebih dari 30\%. Demikian pula, Kementerian Perindustrian akan mendorong industri yang memiliki daya saing di pasar global, termasuk industri otomotif melalui kerjasama dengan industri terkait dari Jepang dan Korea Selatan.

Sejauh ini ada beberapa batasan yang ingin diantisipasi pada tahun 2018, salah satunya adalah penetapan tarif bea masuk di berbagai lokasi internasional untuk produk-produk dari Indonesia (Hartanto, 2018). Ketika kendaraan digunakan, tentu kita tidak ingin menemui kesulitan terutama pada saat dibutuhkan. Salah satu persyaratannya adalah perawatan berkala. Terdapat beberapa manfaat jika melakukan perawatan rutin secara berkala di Auto Family diantaranya performa maksimal, nyaman dan aman, reduksi biaya, reduksi risiko, memperpanjang umur kendaraan, dan mendapatkan claim waranty (Maulana, 2017). Salah satu perawatan berkala yang ditawarkan oleh Auto2000 Setiabudhi adalah penggantian disc brake New Avanza Veloz. Namun terdapat permasalahan dalam prosesnya yaitu terjadinya waste waiting dan motion, waktu proses melebihi standar yang telah ditetapkan oleh Auto2000 Setiabudhi yaitu selama 2 jam, service level rendah hanya berkisar antara 6,59\% hingga $11,76 \%$, serta pencapaian level sigma berkisar antara 2,52 sigma hingga 2,55 sigma. Manfaat yang didapatkan dengan menggunakan pendekatan six sigma yaitu tidak adanya claim after market, meningkatkan level sigma menjadi 5,02, menurunkan nilai variasi proses, dan pencapaian nol problem leakage pada expansion sleeve yoke (Irawan, 2014). Melihat krusialnya permasalahan yang dihadapi oleh Auto2000 Setiabudhi maka dilakukan penelitian "Strategi Operasi Berbasis Lean Six Sigma sebagai Usaha Peningkatan Service Level (Studi Kasus: Auto2000 Setiabudhi)".

\section{Kajian Literatur}

Studi literatur dimulai dari landasan konsep umum (grand theory), berupa ilmu manajemen dan organisasi yang memiliki hubungan dengan teori perantara (middle range theory) yang terdiri dari manajemen operasional dan manajemen kualitas. Middle range theory tersebut tidak lain merupakan konsep utilitas dari teori aplikasi (applied theory) yang digunakan dalam penelitian ini, yaitu Lean Six Sigma serta bermuara pada peningkatan service level di Auto2000 Setiabudhi.

Manajemen didefinisikan sebagai proses perencanaan, pengorganisasian, pengarahan, dan pengendalian penggunaan sumber daya yang tersedia, saling menghormati, memotivasi, dan mendorong antartim kerja, serta memiliki sifat asertif, empati, dan dikomunikasikan secara jelas agar keinginan organisasi dapat dipenuhi secara benar dan efektif (Robbins dan Coulier, 2016; Schermerhorn, et. al., 2016; Daft, 2016). Selain pengertian ini, manajemen juga diartikan dalam berbagai istilah atau sebutan, walaupun berbeda dalam perspektif, konsep manajemen masih mengacu pada perencanaan, pengorganisasian, pengarahan, dan pengendalian antara lain: manajemen sebagai kegiatan proses, manajemen sebagai ilmu dan seni, manajemen sebagai 
profesi, serta manajemen sebagai kumpulan orang untuk mencapai tujuan (Robbins dan Coulier, 2016).

Organisasi adalah suatu sistem yang tersusun dan terkoordinasi dengan mekanisme operasi dan birokrasi yang terlaksana oleh sekumpulan orang secara berkelanjutan sehingga tujuan organisasi dapat dicapai (Daft, 2016; Waldman, 2016; Shafritz, 2016; Robbins dan Judge, 2015; Kreitner dan Kinicki, 2014). Terdapat empat model dalam perilaku organisasi yaitu model otokratik, model kastrodial, model suportif, dan model kolegial (Muchlas, 2012).

Manajemen operasi adalah strategi operasi yang menghasilkan nilai tambah melalui serangkaian proses transformasi sumber daya dan memastikan output yang dihasilkan berhasil dikirim ke pelanggan (Slack, 2016; Heizer dan Render, 2015; Russel, 2013; Daft, 2016). Menurut Heizer dan Render (2015:51), bisnis memenuhi tugas mereka dalam tiga cara yakni bersaing dalam diferensiasi, bersaing dalam biaya, dan bersaing dalam respon. Manajemen kualitas didefinisikan sebagai perpaduan semua fungsi terdokumentasi yang bertujuan memberikan transparansi mengenai bentuk organisasi, teknik dan peralatan organisasi yang kemudian dapat memberi kepuasan kepada konsumen (Prawitra dalam Sutisna, 2008; Nasution, 2010; Gasperz, 2007; Kiran, 2016. Dalam manajemen kualitas terdapat 4 (empat) elemen pokok yang dikemukakan oleh (Gasperz dan Fontana, 2011) antara lain foundation (pondasi), ethics (etika), integrity (integritas), dan trust (kepercayaan). Adapun perbedaan antara metode lean dengan metode Lean Six Sigma antara lain budaya, dasar teori, pola pengelolaan operasional, titik pemecahan masalah, analisis metode, pelaksanaan, proses peningkatan modalitas, dan fokus masalah (Gasperz dan Fontana, 2011).

Penerapan Lean Six Sigma dapat mereduksi waste defect, inventory, over production dan waiting, serta meningkatkan level sigma (Lubis, 2016; Nurprihatin, Yulita dan Caesaron, 2017; Syahroni 2015; Dewi, Setyanto dan Tantrika, 2013; Fransiscus, Juwono dan Astari, 2014). Dari penelitian terdahulu maka dirumuskan proposisi penelitian ini adalah dengan menggunakan strategi operasi berbasis Lean Six Sigma akan meningkatkan Service Level Auto2000 Setiabudhi.

\section{Metode Penelitian}

Flowchart penelitian dapat dilihat pada Gambar 1.

\section{Gambar 1. Desain Penelitian}

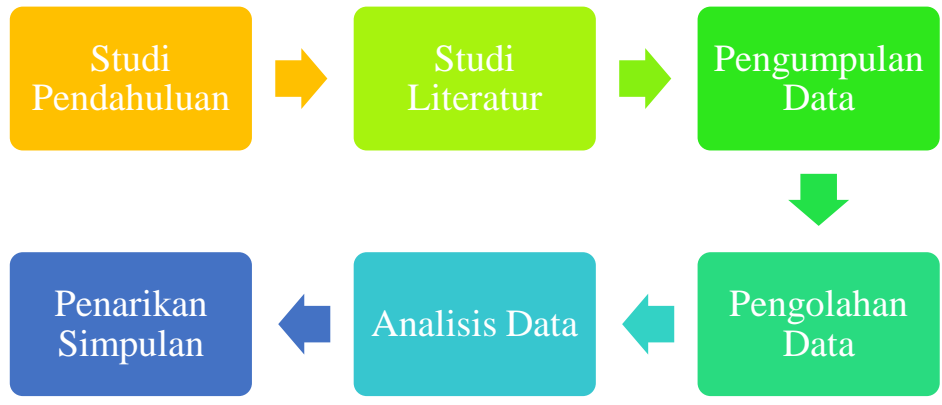

\section{Studi Pendahuluan}

Berdasarkan Gambar 1, bagian ini dilakukan observasi awal untuk mengetahui landasan empiris dari objek penelitian, melakukan observasi mengenai lokus penelitian sehingga dapat menangkap fenomena yang tengah terjadi pada saat penelitian dilakukan. 


\section{Studi Literatur}

Pada bagian ini, tinjauan literatur dilakukan untuk menetapkan landasan teori umum (grand theory) dalam bentuk ilmu manajemen dan organisasi yang memiliki hubungan dengan teori perantara (middle range theory) yang terdiri dari manajemen operasi dan manajemen kualitas. Middle range theory tersebut tidak lain adalah induk dari teori aplikasi (applied theory) yang digunakan dalam penelitian ini, yaitu Lean Six Sigma.

\section{Pengumpulan Data}

Pengumpulan data dilakukan dengan menggunakan beberapa metode antara lain sebagai berikut; 1) Wawancara, wawancara dilakukan terhadap teknisi yang berjumlah 6 orang dan service manager mengenai proses dan kendala yang ditemui dalam proses penggantian disc brake New Avanza Veloz; 2) Observasi, observasi dilakukan untuk mengetahui proses pergantian disc brake New Avanza Veloz; 3) Studi Dokumentasi, studi dokumentasi dilakukan untuk mengetahui waktu proses per stasiun kerja untuk kegiatan penggantian disc brake New Avanza Veloz pada tahun 2017 dan tahun 2018.

\section{Pengolahan Data}

Pemrosesan informasi dilakukan dengan mengikuti siklus DMAIC (Define Measure - Analyze - Improve - Control).

\section{Define}

Tahap define termasuk membuat SIPOC (Supplier - Input - Process - Output Customer) yang digunakan untuk melihat proses bisnis dari pemasok ke pelanggan. Pembuatan Value Stream Mapping digunakan untuk melakukan identifikasi waste yang ada pada proses pergantian disc brake New Avanza Veloz.

\section{Measure}

Tahap Measure dilakukan perhitungan DPMO (Defect - Per - Million Opportunity) waktu proses penggantian disc brake New Avanza Veloz. Perhitungan DPMO dilakukan untuk pengukuran level sigma proses penggantian disc brake New Avanza Veloz.

\section{Analyze}

Tahap Analyze dilakukan identifikasi terhadap faktor-faktor penyebab permasalahan proses penggantian disc brake New Avanza Veloz dengan menggunakan diagram fishbone.

\section{Improve}

Tahap improve dilakukan untuk merancang tindakan perbaikan berdasarkan akar permasalahan proses penggantian disc brake New Avanza Veloz yang telah diidentifikasikan pada tahap analyze dengan menggunakan tabel FMEA (Failure Mode and Effect Aanlysis) untuk mengisi peringkat Risk Priority Number (RPN) dilakukan setelah melakukan Focus Group Discussion (FGD) dengan para teknisi dan service manager.

\section{Control}

Tahap Control dilakukan pengukuran kembali waktu proses penggantian disc brake New Avanza Veloz setelah melakukan tindakan perbaikan yang telah diidentifikasikan pada tahap improve.

\section{Analisis Data}

Analisis data dilakukan untuk membuktikan proposisi berdasarkan hasil pengolahan data yang telah dilakukan pada tahap sebelumnya.

\section{Penarikan Simpulan}

Penarikan simpulan dilakukan untuk menjawab rumusan masalah yang telah dirumuskan pada awal penelitian. Metode penelitian yang dilakukan dalam penelitian ini adalah metode kualitatif berbasis studi kasus eksplanatory dengan menggunakan pendekatan deduktif.

\section{Hasil dan Pembahasan}

Proses penggantian disc brake New Avanza Veloz dapat dilihat pada Gambar 2. 
Gambar 2. Proses Penggantian Disc Brake

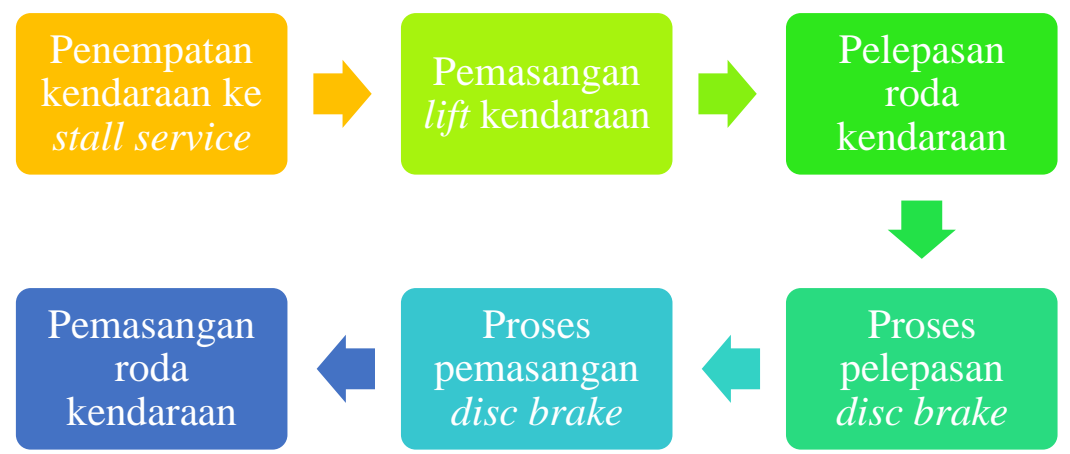

\section{Gambar 3. Rata-Rata Waktu Proses Penggantian Disc Brake New Avanza Veloz}

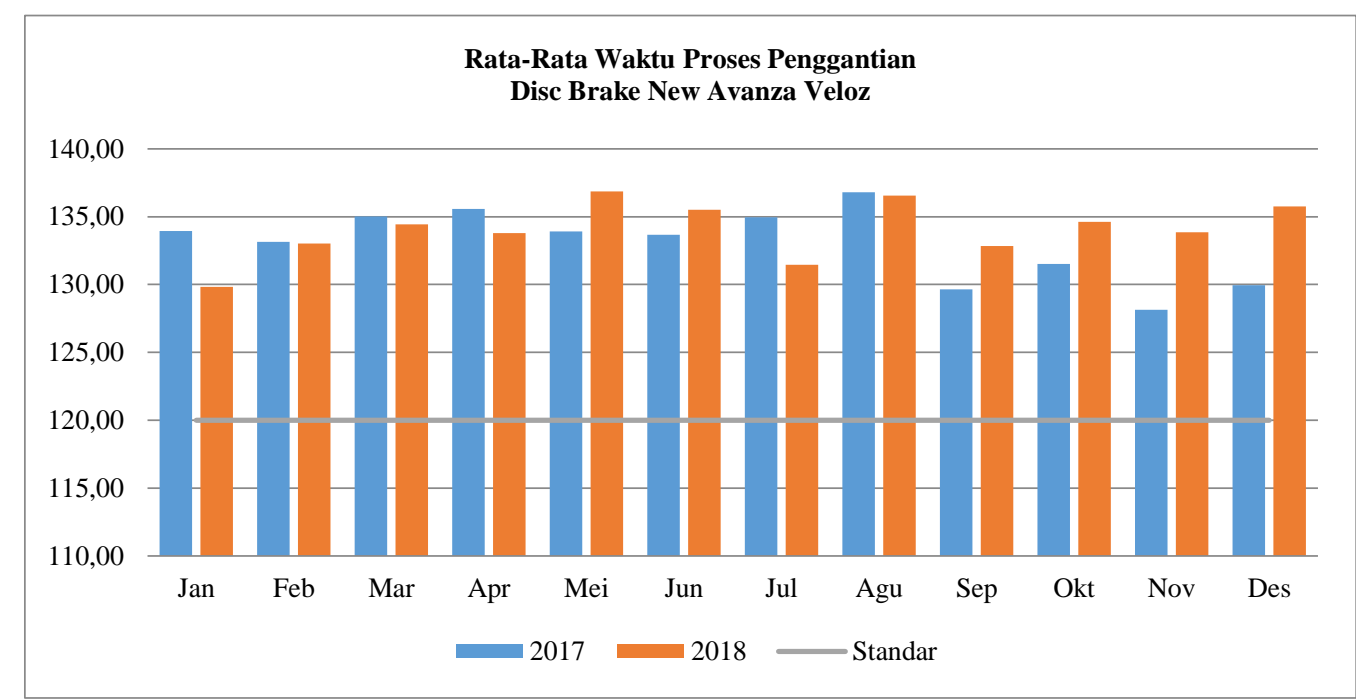

Pada Gambar 3 dapat dilihat bahwa gap antara waktu proses pergantian disc brake New Avanza Veloz dengan standar yang ditetapkan perusahaan yaitu selama 120 menit sebesar $4,82 \%$ dengan nilai gap tertinggi terjadi pada bulan Desember. Hal ini memperlihatkan adanya waste yang terjadi pada proses pergantian disc brake New Avanza Veloz di Auto2000 Setiabudhi.

\section{Tabel 1. Rata-Rata Waktu Proses Penggantian Disc Brake New Avanza Veloz Tahun} 2017 dan 2018

\begin{tabular}{lllllll}
\hline \multirow{2}{*}{ Bulan } & \multicolumn{6}{l}{ Waktu Proses } \\
\cline { 2 - 7 } & 1 & 2 & 3 & 4 & 5 & 6 \\
\hline Rata-rata 2017 & $0: 05: 45$ & $0: 06: 12$ & $0: 05: 19$ & $1: 22: 29$ & $0: 27: 28$ & $0: 05: 48$ \\
\hline Rata-rata 2018 & $0: 05: 50$ & $0: 06: 01$ & $0: 06: 08$ & $1: 22: 54$ & $0: 27: 16$ & $0: 05: 54$ \\
\hline Gap Rata-rata 2017-2018 & $0.00 \%$ & $-0.02 \%$ & $0.72 \% *$ & $0.46 \%$ & $-0.01 \%$ & $0.00 \%$ \\
\hline
\end{tabular}

Keterangan:

1. Penempatan kendaraan ke stall service

2. Pemasangan lift kendaraan

3. Pelepasan roda kendaraan
4. Pelepasan disc brake

5. Pemasangan disc brake

6. Pemasangan roda kendaraan 
Pada Tabel 1 terlihat gap rata-rata waktu proses penggantian disc brake New Avanza Veloz di Auto2000 Setiabudhi terjadi pada stasiun kerja 3 yaitu sebesar $0,72 \%$, namun yang menjadi fokus penelitian adalah proses pelepasan disc brake sebesar $0,46 \%$ yang memakan waktu selama 72,7 menit ekuivalen dengan $60,58 \%$ dari total standar waktu proses penggantian disc brake New Avanza Veloz.

\section{Gambar 4. Service Level Proses Penggantian Disc Brake New Avanza Veloz}

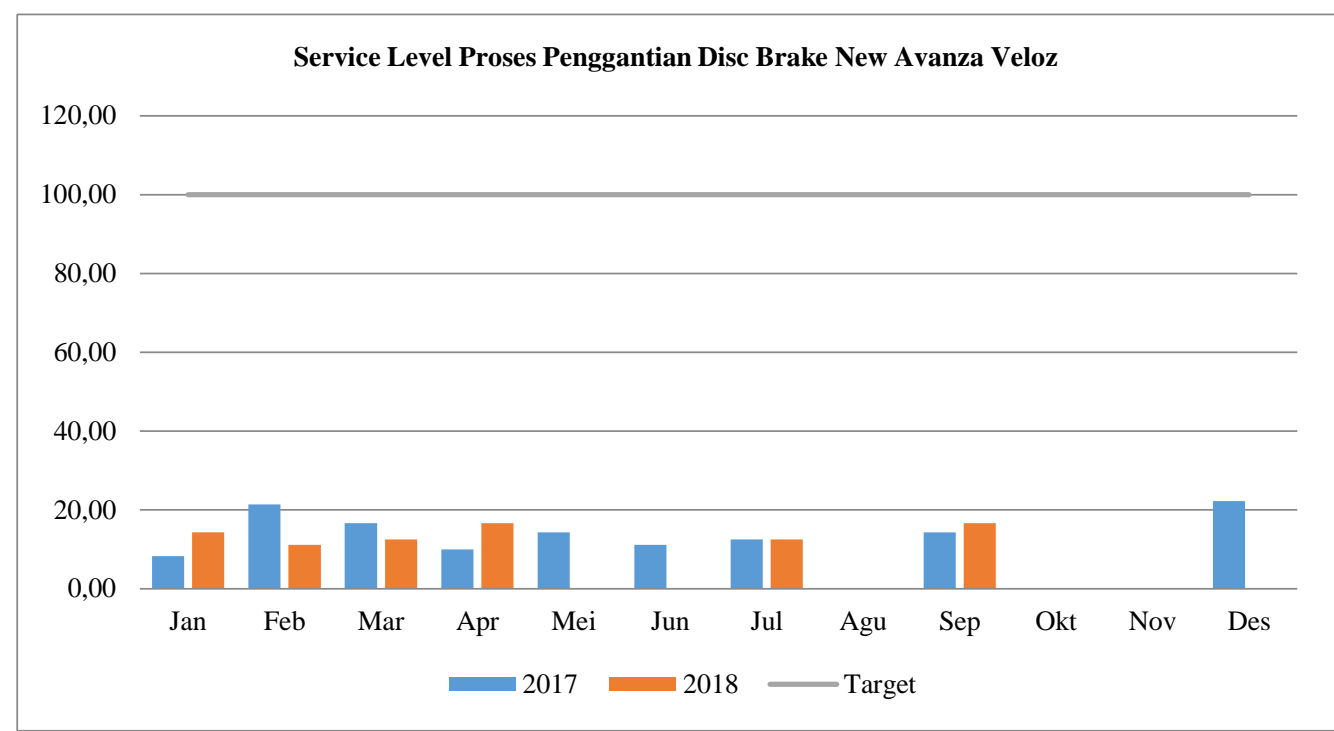

Dari Gambar 4 dapat terlihat bahwa pencapaian service level untuk proses penggantian disc brake New Avanza Veloz sangat rendah pada tahun 2017 dan tahun 2018 yaitu sebesar 8,94\%. Pencapaian service level terendah terjadi pada bulan Agustus, Oktober, dan November yaitu sebesar $0 \%$.

Tahap define merupakan tahap mendefinisikan proses penggantian disc brake New Avanza Veloz di Auto2000 Setiabudhi. Adapun tools yang digunakan adalah diagram SIPOC dan VSM.

Diagram SIPOC menggambarkan aliran proses penggantian disc brake New Avanza Veloz dimulai dari supplier hingga ke customer. Diagram SIPOC dapat dilihat pada Gambar 5.

\section{Gambar 5. Diagram SIPOC Proses Penggantian Disc Brake New Avanza Veloz di} Auto2000 Setiabudhi

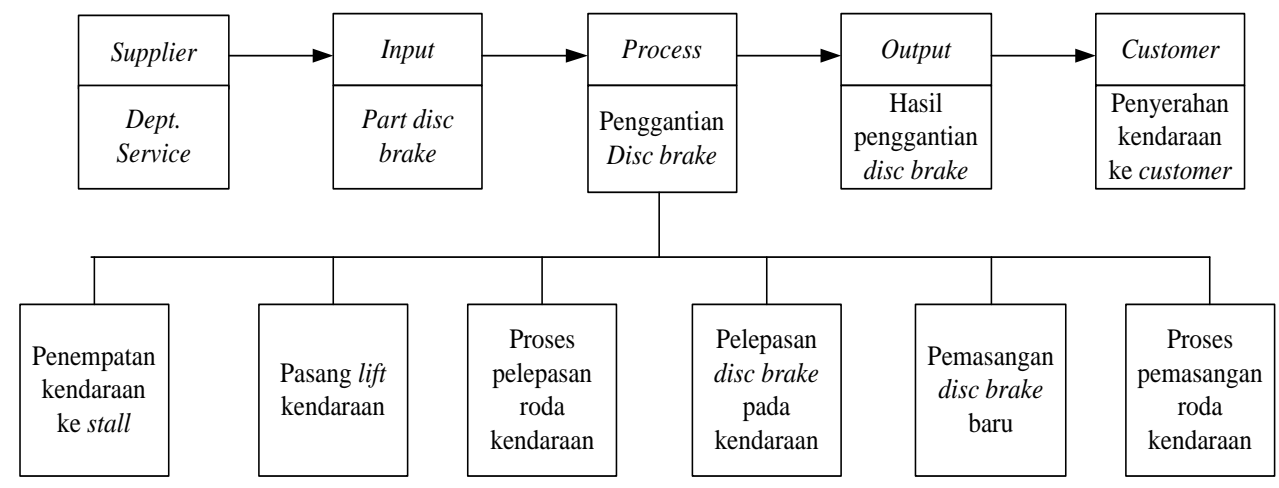


Dari Gambar 5 dapat terlihat bahwa penggantian disc brake New Avanza Veloz berada pada bagian proses. Namun terdapat permasalahan pada proses penggantian disc brake New Avanza Veloz di Auto2000 Setiabudhi yaitu waktu prosesnya melebihi target yang telah ditetapkan dan berimbas pada penurunan service level proses penggantian disc brake New Avanza Veloz.

Value Stream Mapping proses penggantian disc brake New Avanza Veloz di Auto2000 Setiabudhi dapat dilihat pada Gambar 6.

\section{Gambar 6. Value Stream Mapping Kondisi "As Is" Proses Penggantian Disc Brake New Avanza Veloz di Auto2000 Setiabudhi}

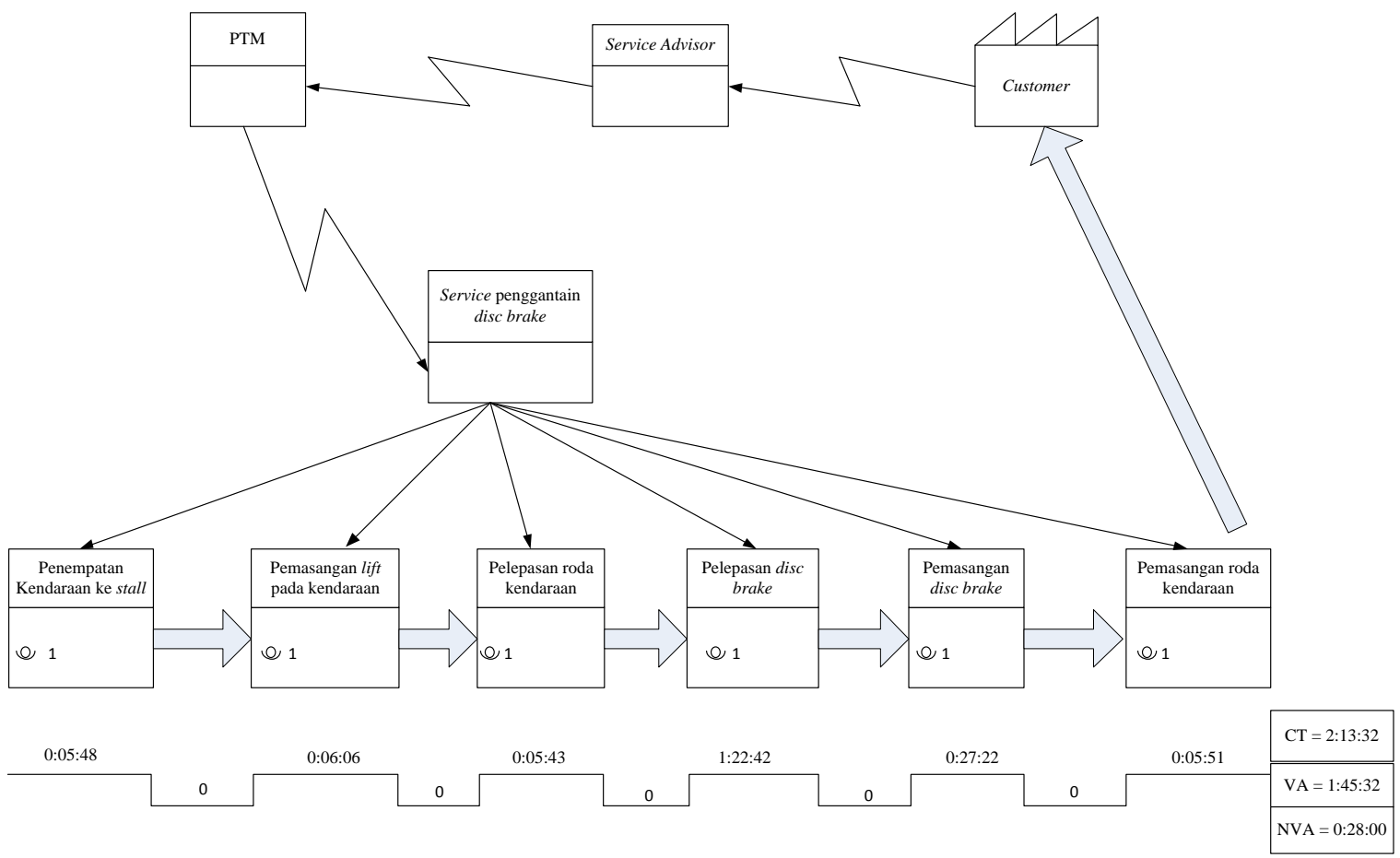

Dari Gambar 6 tersebut dapat diketahui beberapa informasi, diantaranya non value added activities yang dapat dilihat pada Tabel 2, waste yang terjadi dan Critical to Quality (CtQ) pada proses penggantian disc brake New Avanza Veloz di Auto2000 Setiabudhi.

\section{Tabel 2. Non Value Added Activities Proses Penggantian Disc Brake New Avanza Veloz di Auto2000 Setiabudhi}

\begin{tabular}{ll}
\hline Area Proses & Kegiatan \\
\hline Penempatan kendaraan & $\begin{array}{l}\text { Menunggu petugas vallet memindahkan kendaraan sehingga } \\
\text { harus menunggu selama 2, }\end{array}$ \\
\hline Pelepasan roda & $\begin{array}{l}\text { Penyimpanan mur roda kendaraan tidak tersedia di dekat } \\
\text { teknisi, sehingga teknisi harus menyimpan ke ruang mesin } \\
\text { membutuhkan waktu 1' }\end{array}$ \\
\hline Pelepasan disc brake & $\begin{array}{l}\text { Menunggu teknis lain untuk membantu pelepasan disc brake, } \\
\text { sehingga teknisi menunggu 15, }\end{array}$ \\
\cline { 2 - 2 } & $\begin{array}{l}\text { Teknisi membutuhkan istirahat saat pelepasan disc brake } \\
\text { selama 10' }\end{array}$ \\
\cline { 2 - 2 } & $\begin{array}{l}\text { Pergerakan yang dilakukan teknisi dalam proses pelepasan } \\
\text { disc brake dilakukan berulang-ulang }\end{array}$ \\
\hline
\end{tabular}


Dari Tabel 2 didapatkan waste yang terjadi adalah waste waiting yang terjadi pada proses penempatan kendaraan ke stall dan proses pelepasan disc brake. Namun, pada area proses pelepasan roda kendaraan terjadi waste motion.

Sedangkan yang dijadikan sebagai CtQ dalam penelitian ini adalah keenam stasiun kerja proses penggantian disc brake New Avanza Veloz di Auto2000 Setiabudhi yaitu penempatan kendaraan ke stall service, pemasangan lift kendaraan, pelepasan roda kendaraan, pelepasan disc brake, pemasangan disc brake, dan pemasangan roda kendaraan.

Pada tahap measure dilakukan perhitungan level sigma proses penggantian disc brake New Avanza Veloz di Auto2000 Setiabudhi pada tahun 2017 hingga tahun 2018. Level sigma proses penggantian disc brake New Avanza Veloz tahun 2017 hingga tahun 2018 dapat dilihat pada Gambar 7.

\section{Gambar 7. Level Sigma Proses Penggantian Disc Brake New Avanza Veloz}

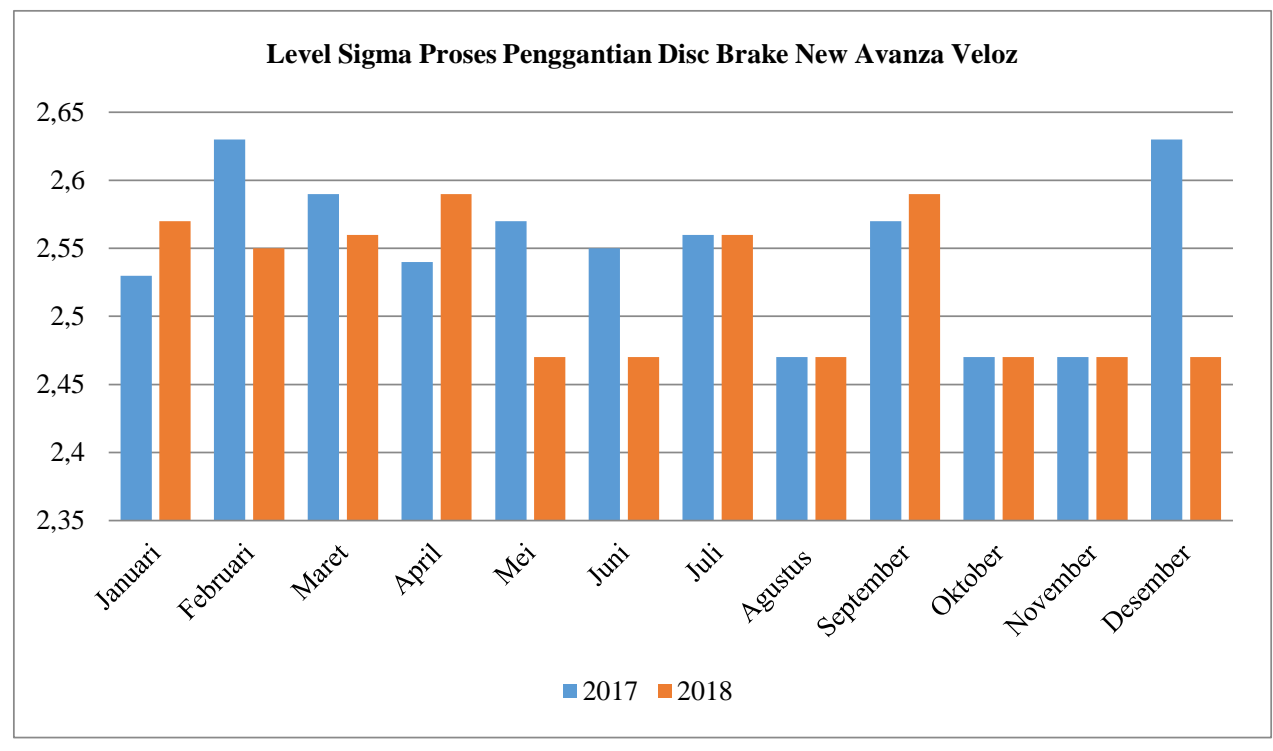

Dari Gambar 7 tersebut dapat dilihat bahwa terdapat penurunan level sigma sebesar $1,11 \%$ dengan penurunan level sigma terbesar terjadi pada bulan Desember yaitu sebesar 6,08\%. Adapun rata-rata pencapaian level sigma proses penggantian disc brake New Avanza Veloz di Auto2000 Setiabudhi sebesar 2,53 sigma. Hal ini menandakan masih masuk dalam rata-rata pencapaian level sigma di Indonesia yaitu dikisaran dua hingga tiga sigma.

Pada tahap analyze dilakukan proses identifikasi faktor-faktor penyebab permasalahan yang terjadi pada proses penggantian disc brake New Avanza Veloz di Auto2000 Setiabudhi. Tools yang digunakan adalah diagram fishbone. Diagram fishbone untuk proses penggantian disc brake New Avanza Veloz dapat dilihat pada Gambar 8. 


\section{Gambar 8. Diagram Fishbone Proses Disc Brake New Avanza Veloz}

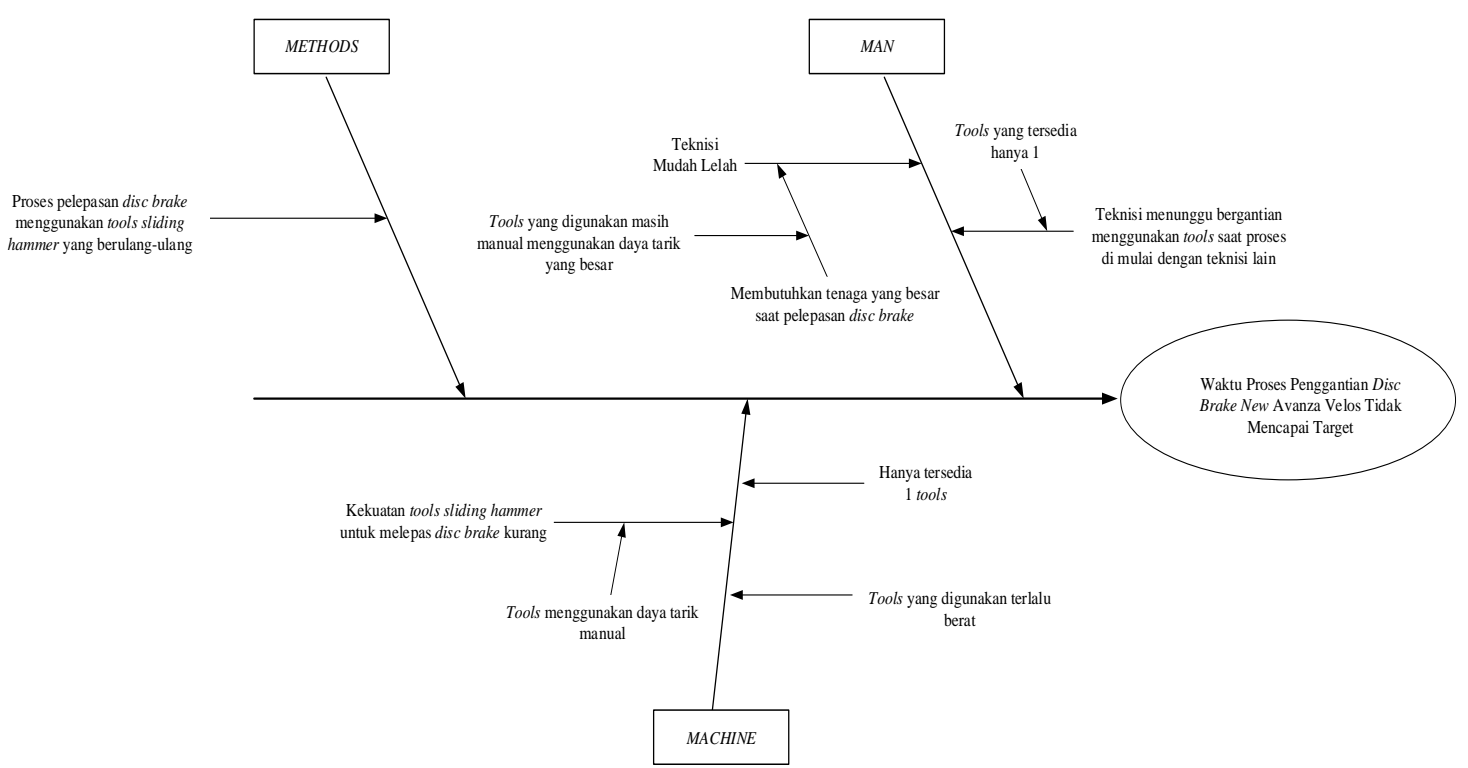

Dari Gambar 8 terlihat bahwa faktor penyebab krusial permasalahan yang terjadi pada proses penggantian disc brake New Avanza Veloz adalah faktor machine dengan beberapa penyebab, diantaranya hanya tersedia satu tools, tools yang digunakan terlalu berat, dan kurangnya kekuatan Tools Sliding Hammer untuk melepas disc brake.

Faktor kedua penyebab permasalahan pada proses penggantian disc brake New Avanza Veloz adalah faktor man dengan beberapa penyebab, yaitu teknisi mudah lelah dan teknisi menunggu bergantian menggunakan tools. Faktor terakhir penyebab permasalahan pada proses penggantian disc brake New Avanza Veloz adalah faktor methods dengan penyebabnya adalah proses pelepasan disc brake dilakukan secara berulang dengan menggunakan Tools Sliding Hammer.
Dalam fase improve, perbaikan dilakukan berdasarkan hasil fase analyze proses penggantian disc brake New Avanza Veloz di Auto2000 Setiabudhi. Peningkatan ini menggunakan metode Failure Mode and Effect Analysis (FMEA) untuk menentukan pemborosan dengan nilai Risk Priority Number $(R P N)$ tertinggi serta memberikan rekomendasi berdasarkan waste yang terjadi.

Nilai Risk Priority Number didapatkan dari hasil perkalian severity, detectability, dan occurence. Peringkat pada tabel Failure Mode and Effect Analysis merupakan hasil Forum Group Discussion (FGD) dengan manajer service dan para teknisi. Tabel Failure Mode and Effect Analysis proses penggantian disc brake New Avanza Veloz dapat dilihat pada Tabel 3

Tabel 3. FMEA Proses Penggantian Disc Brake New Avanza Veloz

\begin{tabular}{lllllll}
\hline Area & Jenis Waste & S & D & O & RPN & Solusi \\
\hline \multirow{2}{*}{ Pelepasan disc brake } & Waiting & 7 & 8 & 6 & 336 & Memperbaiki alat/ membuat alat \\
\cline { 2 - 6 } & Waiting & 6 & 7 & 3 & 126 & baru \\
\cline { 2 - 5 } & Motion & 5 & 7 & 3 & 105 & \\
\hline Pelepasan roda & Motion & 2 & 7 & 2 & 28 & Menyediakan tempat khusus \\
\hline $\begin{array}{l}\text { Penempatan } \\
\text { kendaraan }\end{array}$ & Waiting & 2 & 3 & 3 & 18 & Menambah jumlah valet \\
\hline
\end{tabular}


Dari Tabel 3 dapat diketahui bahwa nilai RPN tertinggi adalah untuk jenis waste waiting dengan solusi memperbaiki tools yang ada atau membuat tools baru. Setelah didiskusikan dengan manajer service dan para teknisi maka dibuatlah tools baru yang akan memudahkan proses penggantian disc brake New Avanza Veloz. Tools baru yang akan mempermudah proses penggantian disc brake New Avanza Veloz dapat dilihat pada Gambar 9.

\section{Gambar 9. Tayanami Sliding Hammer Baru}

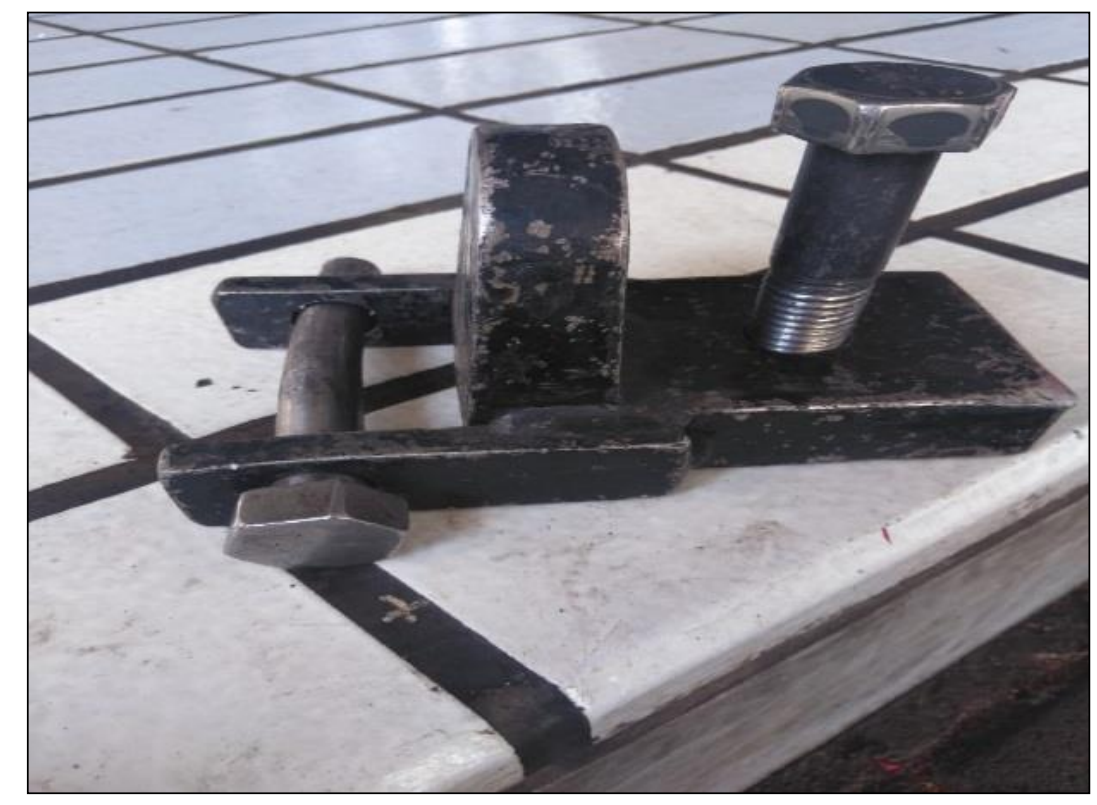

Tayanami yang dibuat akan mereduksi waste waiting dan motion pada area pelepasan disc brake. Hal ini dikarenakan alatnya jauh lebih ringan dibandingkan tools yang lama sehingga akan mereduksi waktu proses penggantian disc brake New Avanza Veloz dan secara otomatis meningkatkan service level Auto2000 Setiabudhi.

Tahap control merupakan tahap continuous improvement yang dilakukan teknisi dengan menggunakan alat baru. Tahap continuous improvement dilakukan sebagai berikut:

1. Pelaksanaan prosedur kerja penggunaan alat baru dalam proses penggantian disc brake New Avanza Velos dengan cara membuat lembar urutan kerja (Work Sequence Sheet).

2. Pembuatan SOP penggunaan alat baru yang telah disetujui oleh pihak perusahaan.
3. Pelaksanaan pengecekan alat baru dengan cara membuat form yang berisi laporan pengecekan kondisi alat baru.

4. Pengamatan hasil penggantian disc brake setelah menggunakan alat baru dengan cara membuat form yang berisi waktu lamanya proses pekerjaan penggantian disc brake setelah menggunakan alat baru.

Pada tahap define setelah menggunakan takayanami maka non value added activities bisa direduksi sebesar 89,29\% dan bisa mereduksi waste yang terjadi pada area proses pelepasan disc brake. Pada tahap measure setelah menggunakan takayanami maka waktu proses penggantian disc brake New Avanza Veloz dapat direduksi sebesar $50,03 \%$ dan peningkatan level sigma sebesar $57,76 \%$.

Pada tahap analyze, setelah menggunakan takayanami maka faktor kelelahan teknisi dan pengulangan gerakan proses pelepasan disc brake dapat 
direduksi cukup signifikan. Pada tahap improve setelah menggunakan takayanami terjadi penurunan RPN pada area proses pelepasan disc brake New Avanza Veloz berkisar antara 92,38\% hingga $99,4 \%$, dan nilai reduksi tertinggi terjadi pada kegiatan istirahat teknisi saat pelepasan disc brake. Tahap control setelah menggunakan takayanami dilakukan dengan mengisi formulir laporan pengecekan alat baru dan mengisi formulir laporan hasil penggantian disc brake.

\section{Kesimpulan}

Berdasarkan hasil dan pembahasan penelitian tersebut, terdapat tiga faktor penyebab permasalahan yang terjadi pada proses penggantian disc brake New Avanza Veloz yaitu faktor Machine, Man, dan Methods. Solusi yang diambil untuk mengatasi permasalahan yang terjadi pada proses penggantian disc brake New Avanza Veloz adalah penggunaan Takayanami sebagai tools baru, dan keuntungan yang didapatkan adalah mereduksi waktu proses penggantian disc brake New Avanza Veloz, mereduksi nilai Risk Priority Number dan waste yang terjadi pada area proses pelepasan disc brake, meningkatkan level sigma, serta meningkatkan Service Level Auto2000 Setiabudhi.

\section{Daftar Pustaka}

Daft, R. L. (2016). Organization Theory \& Design. Boston: MA Cengage Learning.

Dewi, W., R., Setyanto, N., W., \& Tantrika, C., F., M. (2013). Implementasi Metode Lean Six Sigma Sebagai Upaya Meminimasi Waste pada PT. Prime Line International. Jurnal Rekayasa dan Manajemen Sistem Industri, 1(1), 47-56. Diakses dari http://jrmsi.studentjournal.ub.ac.id/i ndex.php/jrmsi/article/view/12/24
Fransiscus, H., Juwono, C., P., \& Astari, I., S. (2014). Implementasi Metode Six Sigma DMAIC untuk Mengurangi Paint Bucket Cacat di PT. X. Jurnal Rekayasa Sistem Industri, 3(2), 53-64. doi: https://doi.org/10/26593/jrsi.v3i2.12 97.53-64

Gasperz, V. (2007). Team-Oriented Problem Solving Paduan Kreatif Solusi Masalah untuk Sukses. Jakarta: PT. Gramedia Pustaka Utama.

Gasperz, V., \& Fontana, A. (2011). Lean Six Sigma for Manufacturing and Services. Bogor: Vinchirsto Publication.

Hartanto, A. (10 November 2017). Menperin Apresiasi Perkembangan Industri Otomotif Indonesia. Diakses dari https://kemenperin.go.id/artikel/179 59/Menperin-ApresiasiPerkembangan-Industri-OtomotifIndonesia

Heizer, J., \& Render, B. (2015). Manajemen Operasi: Manajemen Keberlangsungan dan Rantai Pasokan, edisi 11. Jakarta: Salemba Empat.

Irawan, S. V. (2014). Pendekatan Metode Six Sigma (DMAIC) dan proses Audit (CPPP) untuk Peningkatan Kualitas di PT. IGP. Jurnal Penelitian dan Aplikasi Sistem dan Teknik Industri, 8(3), 411-422. Diakses dari https://www.neliti.com/publications /182902/pendekatan-metode-sixsixma-dmaic-dan-proses-auditcppp-untuk-peningkatan-kualit\#cite

. (10 November 2018). Sektor Otomotif Berpeluang Melaju. Diakses dari https://www.gaikindo.or.id/201 8-sektor-otomotif-berpeluangmelaju/ 
Kiran, D. R. (2016). Total Quality Management: Key Concepts and Case Studies. ButterworthHeinemann: Elsevier.

Kreitner, R., \& Kinicki, A. (2014). Perilaku Organisasi. Jakarta: Salemba Empat.

Lubis, M. Y. (2016). Analisis Penerapan Lean Six Sigma pada Proses Produksi Part Body Casing Meter Air di PT. MRN. Tesis. Universitas Pasundan.

Maulana, A. (22 Desember 2017). Keuntungan Servis Berkala Mobil di Bengkel Resmi. Diakses dari https://amp.kompas.com/otomo tif/read/2017/12/22/154200615/keu ntungan-servis-berkala-mobil-dibengkel-resmi

Muchlas, M. (2012). Perilaku Organisasi. Yogyakarta: Gadjah Mada University Press.

Nasution, M. N. (2010). Manajemen Mutu Terpadu (Total Quality Management) Edisi 3. Jakarta: Ghalia Indonesia.

Nurprihatin, F., Yuliata, N. E., \& Caesaron, D. (2017). Usulan Pengurangan Pemborosan pada Proses Penjahitan Menggunakan Metode Lean Six Sigma, Bandung: Seminar Nasional Akuntansi dan Bisnis (SNAB) Program Studi Akuntansi dan Bisnis, Manajemen Universitas Widyatama, 809-818. Diakses dari https://repository.widyatama.ac.id/x mlui/handle/123456789/8580
Robbins, S. P., \& Coulier, M. (2016). Management 13th edition. Boston: Pearson.

Robbins, S. P., \& Judge, t. A. (2015). Perilaku Organisasi Edisi 16. Jakarta: Salemba Empat.

Russel, R. S. (2013). Operation Management: Creating Value Along the Supply Chain. Hoboken: Wiley.

Schermerhorn, J. R., Davidson, P., Factor, A., Poole, D., Woods, P., Simon, A., \& McBarron, E. (2016). Management 6th Asia - Pacific edition. Milton: QLD John Wiley \& Sons Australia.

Shafritz, J. M., Ott, J. S., \& Jang, Y. S. (2016). Classic of Organization Theory eight edition. Boston: MA Cengage Learning.

Slack, N., Joner, A. B., \& Johnston, R. (2016). Operation Management 8th edition. Harlow: Pearson Education Limited.

Sutisna, S. (2008). Perilaku Konsumen dan Komunikasi Pemasaran Pengantar. Bandung: PT. Remaja Rosdakarya.

Syahroni, F. R. (2015). Mereduksi Waste berdasarkan Produksi Susu Pasteurisasi dengan Pendekatan Lean Six Sigma Studi Kasus: KUD Nadhi Murni. Skripsi. Institut Teknologi Sepuluh November.

Waldman, D. E., \& Jensen, E. J. (2016). Industrial Organization Theory and Practice, fourth edition. London: Routledge. 